\title{
Toxoplasma gondii'nin Inhouse Gerçek Zamanlı Polimeraz Zincir Reaksiyonu ile Saptanmasında Yöntemin Doğrulanması
}

\section{Method Verification of Inhouse Real-time Polymerase Chain Reaction for Detection of Toxoplasma gondii}

\author{
Selma USLUCA ${ }^{1}$, Bekir ÇELEBi ${ }^{2}$, Cahit BABÜR ${ }^{1}$ \\ ${ }^{1}$ Halk Sağlığı Genel Müdürlüğü, Mikrobiyoloji Referans Laboratuvarları ve Biyolojik Ürünler Daire Başkanlığı \\ Ulusal Parazitoloji Referans Laboratuvarı, Ankara. \\ ${ }^{1}$ General Directorate of Public Health, Department of Microbiology Reference Laboratories and Biological Products, \\ Ankara, Turkey. \\ 2 Halk Sağlığı Genel Müdürlüğü, Zoonotik ve Vektörel Hastalıklar Daire Başkanlığı, Ankara. \\ 2 General Directorate of Public Health, Department of Zoonotic and Vectorial Diseases, Ankara, Turkey.
}

Makale Atıfı: Usluca S, Çelebi B, Babür C. Toxoplasma gondii'nin inhouse gerçek zamanlı polimeraz zincir reaksiyonu ile saptanmasında yöntemin doğrulanması. Mikrobiyol Bul 2019;53(4):442-450.

\section{ÖZ}

Toksoplazmozis tüm dünyada insanlarda en sık görülen paraziter enfeksiyonlardan biridir. Özellikle immün sistemi sağlam konaklarda asemptomatik ve kendini sınırlayan bir enfeksiyon şeklinde görülmektedir. Bununla birlikte gebelerde ve immün sistemi baskılanmış hastalarda ciddi komplikasyonlara neden olabilmektedir. Tanısında serolojik ve moleküler yöntemler kullanılmaktadır. Birçok hastalıkta olduğu gibi, moleküler yöntemler özellikle tanı konulma süresinin kısalmasını sağladığı için daha çok tercih edilmektedir. Çalışmamızda Toxoplasma gondii'nin ticari kit kullanılmadan düşük maliyetli, kantitatif sonuç verebilen, hızı ve güvenilir bir moleküler yöntemle belirlenmesi ve ayrıca yöntemin doğrulanmasından sonra rutin hasta örneklerine uygulanması amaçlanmıştır. Laboratuvarımızda fare pasajı ile sürdürülmekte olan T.gondii suşundan (14.000 takizoit/ml), ticari bir DNA ekstraksiyon kiti ile üretici firmanın önerileri doğrultusunda DNA ekstraksiyonu yapılmıştır. Elde edilen DNA örneğinden (14.000 genomik DNA/ml) hazırlanan seri dilüsyonlarla inhouse gerçek zamanlı polimeraz zincir reaksiyonu (Rt-PCR) yöntemi ile saptama sınır değeri ve buna göre yüksek ve düşük pozitiflik oranları belirlenmiştir. Testin doğrulanması için doğruluk ve kesinlik çalışmaları TG-F, TG-R primerleri ve TaqMan TG prob kullanılarak Lightcycler 96 realtime PCR cihazı (ThermoFisher Scientific, ABD)'nda gerçekleştirilmiştir. DNA ekstraksiyonu sonucu elde edilen DNA örneğinin seri dilüsyonlarıyla yapılan çalışma sonucunda testin saptama sınır değeri $10^{-3}$ dilüsyon (0.028 kopya/reaksiyon) olarak belirlenmiştir. Yüksek pozitif olarak $10^{-1}$ dilüsyon (2.8 kopya/reaksiyon), düşük pozitif olarak $10^{-2}$ dilüsyon ( 0.28 kopya/reaksiyon) kabul edilerek yöntemin doğrulanması amacıyla çalışmalar gerçekleştirilmiştir. Testin doğruluk çalışması CV değeri yüksek pozitif örnek için 0.62 , düşük pozitif örnek için 0.14 olarak belirlenmiş̧ir. Çalışma içi kesinlik çalışması CV değeri yüksek pozitif örnek için 0.62 , düşük pozitif örnek için 0.14 olarak belirlenirken, çalışmalar arası kesinlik çalışması CV değeri yüksek pozitif örnek için 1.03, düşük pozitif örnek için 2.34 olarak hesaplanmıştır. Çalışma sonu- 
cunda korelasyon katsayısı 0.99 olarak belirlenmiştir. Toksoplazmozisin moleküler yöntemlerle tanısında kullanılan ticari yöntemlerin uygulanması kolay olmasına rağmen, maliyetlerinin yüksek olması nedeniyle birçok laboratuvar tarafından alternatif yöntemler geliştirilmeye çalışılmaktadır. Çalışmamızda kullanılan inhouse Rt- PCR yönteminin varyasyon katsayısının \%15'in altında olduğu belirlenmiştir ve testin rutin laboratuvar çalışmalarına uygun olduğuna karar verilmiştir.

Anahtar kelimeler: Toxoplasma gondii; gerçek zamanlı polimeraz zincir reaksiyonu; yöntem verifikasyon.

\section{ABSTRACT}

Toxoplasmosis is one of the most common parasitic infection in humans. Serological and molecular methods are used for diagnosis. Molecular methods are becoming increasingly preferred, since they lead to shortening of diagnostic time. In our study, it was aimed to determine Toxoplasma gondii by a cost-effective, quantitative, fast and reliable method without using a commercial kit, and apply method verification. T.gondii strain which was continued by mouse inoculation in our laboratory was used for method verification study. For this purpose DNA extraction was performed using a commercial kit. The limit of detection and, high and low positivity rates were determined by serial dilutions of DNA sample. Accuracy and certainty studies were performed using with TG-F, TG-R primers and TaqMan TG probe for method verification of the test. In the study with serial dilutions of DNA sample, detection limit was determined as $10^{-3}$ dilutions ( 0.028 copies/reaction). Furthermore $10^{-1}$ dilution ( 2.8 copies/reaction) was considered as high positive, $10^{-2}$ dilution ( 0.28 copies/reaction) was considered as low positive and method verification studies were performed. The accuracy of test was determined as 0.62 for high positive samples and 0.14 for low positive samples. CV value of intra-assay certainty was 0.62 for high positive samples and 0.14 for low positive samples, whereas, CV value of inter-assay certainty was calculated as 1.03 for high positive samples and 2.34 for low positive samples. Correlation coefficient was determined as 0.99 . The coefficient of variation of inhouse realtime PCR method used in our study was found to be below $15 \%$, and it was decided to be suitable for routine laboratory studies.

Keywords: Toxoplasma gondii; real-time polymerase chain reaction; method verification.

\section{Giriş̧}

Toksoplazmozis insanlarda en sık görülen paraziter enfeksiyonlardan biridir. Tanısında serolojik, moleküler ve kültür yöntemleri kullanılmaktadır. Serolojide en sık "Enzyme linked immunosorbent assay (ELISA)" IgM, IgG ve IgG avidite testleri kullanılmaktadır. Ancak serolojik testlerle saptanabilen immün reaksiyonun geç ortaya çıkması nedeniyle tanı gecikmektedir ${ }^{1,2}$. IgG avidite testiyle geçirilmiş veya yakın zamanda edinilmiş enfeksiyonun ayrımı yapılabilmektedir. IgG yanıtının oluşması bireyler arasında farkıııı göstermektedir. Düşük aviditeli antikorlar aylarca, hatta bir yıldan fazla devam etmekte, bu hastalarda tek başına avidite testi ile akut enfeksiyon düşünülerek sonuç yanlış yorumlanabilmektedir ${ }^{2}$. ELISA testlerinde çapraz reaksiyondan kaynaklanabilecek yanlış negatiflik veya yanlış pozitiflik durumunda uygun altyapıya sahip laboratuvarlarda serolojik testlere ek olarak moleküler testlerin uygulanmasıyla daha güvenilir sonuçlar elde edilebilecektir ${ }^{3}$. Aktif toksoplazmozis olgularının çoğu latent enfeksiyonların reaktivasyonundan kaynaklanmaktadır. Bu nedenle, dokularda veya vücut sıvılarında polimeraz zincir reaksiyonu (PCR) yöntemiyle parazitin doğrudan gösterilmesi oldukça yararlıdır ${ }^{1}$. PCR ve kantitatif PCR gibi daha verimli ve güvenilir yöntemler geliştirilmeye çalışılmak- 
tadır ${ }^{2}$. PCR ile parazit DNA'sının saptanması, serolojik testlerde olduğu gibi hastanın immün durumuna bağlı olmadığından bu yöntemler klasik yöntemlerin yerini almıştır ${ }^{4,5}$. Gerçek zamanlı PCR (Rt-PCR)'de ürün miktarıyla orantılı floresan artışıla kantitasyon belirlenmektedir ${ }^{6}$. Floresan prob kullanılarak kantitatif Rt-PCR en duyarlı yöntemdir ${ }^{7}$. Ancak uygulanan DNA ekstraksiyon yöntemi, primerler ve PCR protokollerinin çeşitliliği ve standardizasyon eksikliğinden dolayı performans farklılıkları görülmekte, duyarlılık problemi devam etmektedir. Bunun nedeni parazit yükünün genellikle düşük olması ve gelişmiş laboratuvarlarda bile tanısal duyarlılığın \%80'in altında kalmasıdır. Birçok laboratuvar kendi geliştirdikleri inhouse yöntemi uygulamaktadır. Moleküler tanı için dış kalite kontrol değerlendirmeleri veya laboratuvarlar arası karşılaştırma çalışmaları da oldukça azdır ${ }^{4}$. Bu nedenle her laboratuvarın uygulamakta olduğu PCR tekniğini standardize etmesi, hem doğru hasta tanısı, hem de güvenilir ülke verileri açısından önem arz etmektedir. Bir test prosedürünün rutin olarak uygulanması için doğrulama yöntemi oluşturulması şarttır ${ }^{2}$. Çalışmamızda T.gondii'nin ticari kit kullanılmadan düşük maliyetle, kantitatif sonuç verebilen, hızlı ve güvenilir bir moleküler yöntemle saptanması ve bu yöntemin doğrulamasının yapılarak, rutin hasta örneklerinin çalışılmasına başlanması amaçlanmıştır.

\section{GEREÇ ve YÖNTEM}

Laboratuvarımızda fare pasajı ile sürdürülmekte olan T.gondii suşundan (14.000 takizoit/ml) DNA ekstraksiyon kiti ile (QIAmp DNA mini kit, Qiagen, Almanya) üretici firmanın önerileri doğrultusunda DNA ekstraksiyonu yapıldı. Elde edilen DNA örneğinden (14.000 genomik DNA/ml) hazırlanan seri dilüsyonlarla inhouse Rt-PCR yöntemi ile saptama sınır değeri ve buna göre yüksek ve düşük pozitiflik oranları belirlendi. Negatif kontrol olarak RNAase/DNAse içermeyen su kullanıldı. Testin doğrulanması için doğruluk ve kesinlik çalışmaları TG-F, TG-R primerleri ve TG prob (Metabion, Almanya), LightCycler prob mastermiks (Roche, Mainnheim, Almanya) kullanılarak LightCycler 96 real-time PCR (Roche, Mainnheim, Almanya) cihazında gerçekleştirildi.

\section{Inhouse Gerçek Zamanlı Polimeraz Zincir Reaksiyonu}

PCR çalışmasında Lin ve arkadaşlarının ${ }^{8}$ önerdiği, T.gondii B1 geninin insersiyon sekans bölgesini hedefleyen TG-F (5'-CTT CGT CCA AGC CTC CGA-3'), TG-R (5'-GAC GCT TTC CTC GTG GTG AT-3') primerleri ve 6-FAM-TCT GTG CAA CTT TGG TGT ATT CGC AG-BHQ-1 taqman prob kullanıldı. Sentezlenen primerler ve probun en iyi çalışma konsantrasyonunu belirlemek için optimizasyon çalışması yapıldı. Bu çalışma sonucuna göre $20 \mu \mathrm{l}$ reaksiyon miksi içerisinde, $10 \mu \mathrm{l}$ LightCycler prob karışımı, her bir primerden $1 \mu \mathrm{l}(10 \mathrm{pmol}), 0.4 \mu \mathrm{l}(4 \mathrm{pmol})$ prob, $5.6 \mu \mathrm{l}$ moleküler grade su ve $2 \mu \mathrm{l}$ DNA olacak şekilde reaksiyon hacmi düzenlendi. Isı döngüsü $95^{\circ} \mathrm{C} 5 \mathrm{dk}$ ön denatürasyon, 40 döngü iki basamaklı $95^{\circ} \mathrm{C} 15$ sn denatürasyon, $60^{\circ} \mathrm{C} 30$ sn bağlanma-uzama şeklinde düzenlendi. 


\section{Saptama Sınır Değeri Çalışması}

Laboratuvarımızda fare pasajı ile sürdürülmekte olan T.gondii suşudan (14.000 takizoit/ml), $200 \mu \mathrm{l}$ (2800 takizoit) kullanılarak ticari kit ile DNA ekstraksiyonu yapıldı. Ekstraksiyon sonunda $200 \mu \mathrm{l}$ (2800 genomik DNA) elüsyon tamponu içerisinde DNA elde edildi. PCR'de $2 \mu$ l DNA kullanıldı. Bu DNA örneğinin 1/10 sulandırımlarla hazırlanan seri dilüsyonları ile saptama sınır değeri çalışması yapıldı ve testin yüksek ve düşük pozitiflik oranları belirlendi.

\section{Yöntemin Doğrulama Çalışması}

Doğrulama çalışması için üçer adet yüksek ve düşük pozitif ve negatif örnek birer kez çalışıldı. Kesinlik çalışmaları, çalışma içi ve çalışmalar arası olmak üzere iki şekilde uygulandı. Çalışma içi kesinlik için üçer adet yüksek ve düşük pozitif örnek birer kez çalışıldı, çalışmalar arası kesinlik için birer adet yüksek ve düşük pozitif örnek üç kez çalışıldı. Elde edilen sonuçlardan doğruluk ve kesinlik çalışmalarının varyasyon katsayısı (\%CV) hesaplandı. \%CV hesaplamak için öncelikle standart sapma ve ortalama hesaplandı. Standart sapmanın ortalamaya bölünmesiyle varyasyon katsayısı elde edildi. Tek değişkenli verilerde, özellikle ölçekler birbirinden çok farklı olduğunda varyasyon katsayısının kullanılmasının, standart sapmadan daha faydalı olduğu bildirilmektedir ${ }^{9}$.

Yöntemin doğrulaması çalışmasının sonuçlarının değerlendirilmesi aşamasında Cumitech 31 A, 2009 referans alındı ${ }^{10}$. PCR sonuçları amplifikasyon eğrisine göre değerlendirildi.

\section{BULGULAR}

Elde edilen DNA örneğinin seri dilüsyonlarıyla yapılan çalışmanın sonucunda testin saptama sınır değeri $10^{-3}$ dilüsyon olarak belirlenmiştir. Yüksek pozitif olarak saptama sınır değerinden $2 \log _{10}$ daha yüksek değer olan $10^{-1}$ dilüsyon, düşük pozitif olarak ise saptama sınır değerinden $1 \log _{10}$ daha yüksek değer olan $10^{-2}$ dilüsyon kabul edilmiştir ve yöntem doğrulaması çalışmaları gerçekleştirilmiştir.

Testin saptama sınır değeri ve yüksek-düşük pozitiflik oranları Tablo I'de, saptama sınır değeri çalışmasına ait amplifikasyon eğrileri Şekil 1'de, doğrulama çalışmasına ait CT değerleri Tablo II'de, doğrulama çalışmasına ait amplifikasyon eğrileri Şekil 2'de, kesinlik çalışmasına ait CT değerleri Tablo III'te, kesinlik çalışmasına ait amplifikasyon eğrileri Şekil 3'te, yöntem doğrulama çalışmalarında, doğruluk ve kesinlik çalışmalarına ait CV değerleri Tablo IV'te gösterilmiştir.

Tablo I. Testin Saptama Sınır Değeri ve Yüksek-Düşük Pozitiflik Oranları

\begin{tabular}{ll} 
Saptama sınır değeri & $10^{-3}$ dilüsyon (0.028 kopya/reaksiyon) \\
Yüksek pozitif & $10^{-1}$ dilüsyon (2.8 kopya/reaksiyon $)$ \\
Düşük pozitif & $10^{-2}$ dilüsyon $(0.28$ kopya/reaksiyon $)$ \\
\hline
\end{tabular}




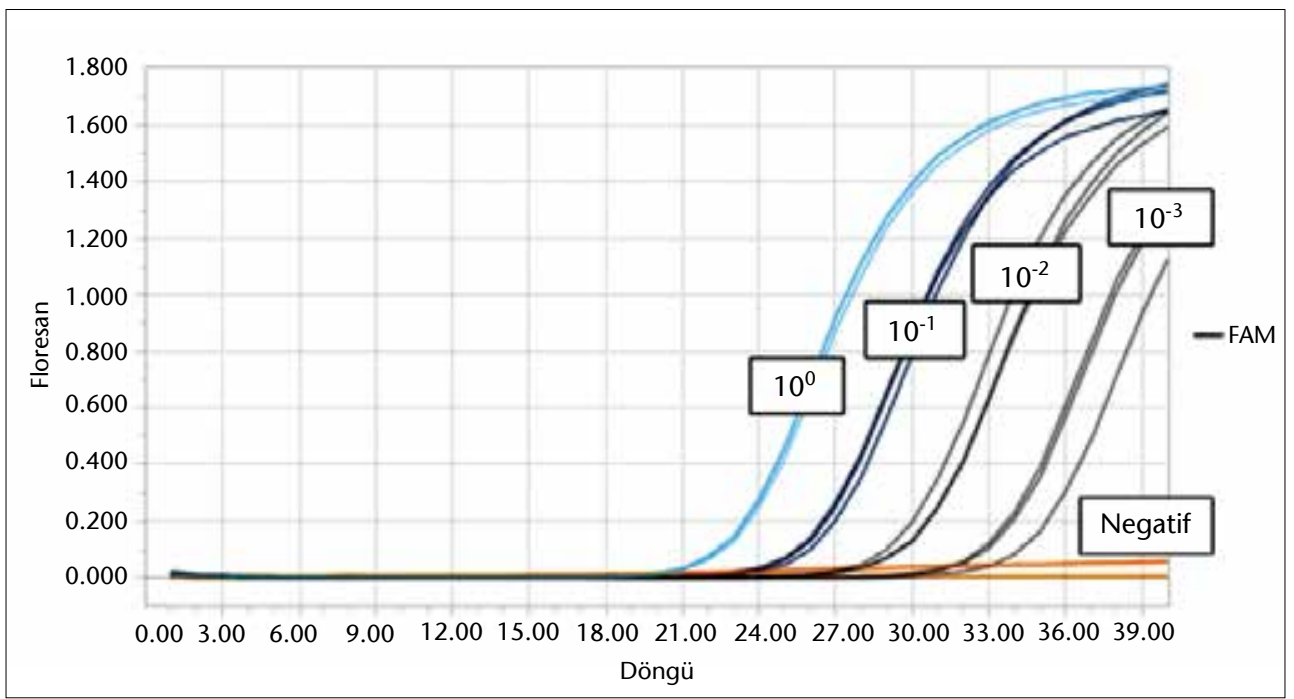

Şekil 1. Saptama sınır değeri çalışmasında $10^{0}$ ile $10^{-3}$ arası DNA dilüsyonlarına ait amplifikasyon eğrileri.

\begin{tabular}{|ll}
\hline \multicolumn{2}{l}{ Tablo II. Doğrulama Çalısmasına Ait CT Değerleri } \\
\hline Örnek adı & CT değeri \\
\hline Yüksek pozitif $1\left(10^{-1}\right)$ & 24.98 \\
Yüksek pozitif $2\left(10^{-1}\right)$ & 24.82 \\
Yüksek pozitif $3\left(10^{-1}\right)$ & 25.13 \\
Düşük pozitif $1\left(10^{-2}\right)$ & 28.14 \\
Düşük pozitif $2\left(10^{-2}\right)$ & 28.21 \\
Düşük pozitif $3\left(10^{-2}\right)$ & 28.14 \\
Negatif 1 & - \\
Negatif 2 & - \\
Negatif 3 & - \\
\hline
\end{tabular}

Elde edilen CV değerleri, doğrulama kabul kriterleri olan \%15'in altında bulunmuştur. Yöntem doğrulama çalışmasında kullanılan DNA dilüsyonlarının $\left(10^{0}-10^{-3}\right)$ doğruluğunu, DNA kalitesini ve reaksiyon verimliliğini gösteren sonuçlar Şekil 4'te verilmiştir.

Korelasyon katsayısı 0.99, standart eğrinin eğimi -3.5 ve verimlilik \%90 olarak saptanmıştır.

\section{TARTIŞMA}

T.gondii'nin saptanmasında sıklıkla B1-, 18S rRNA-, P30-genleri, 529 bp tekrarlayan bölgesi ya da AF146527 elementine yönelik primerler kullanılmaktadır. Genomdaki yüksek kopya sayısına sahip genleri çoğaltan PCR yöntemlerinin duyarlılığının daha yüksek 


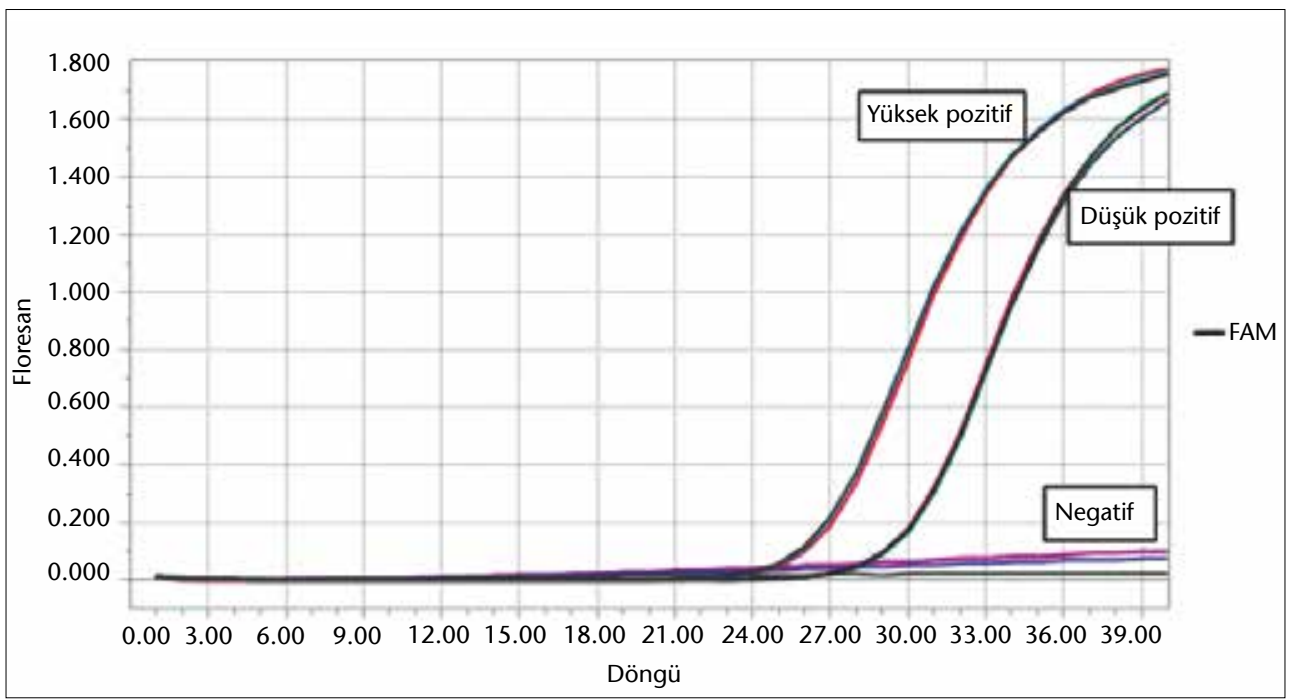

Şekil 2. Doğrulama çalışmasında yüksek pozitif ve düşük pozitif örneklere ait amplifikasyon eğrileri.

\begin{tabular}{|ll|}
\hline \multicolumn{2}{|l|}{ Tablo III. Kesinlik Çalışmasına Ait CT Değerleri } \\
\hline Örnek adı & CT değeri \\
\hline Yüksek pozitif $1\left(10^{-1}\right)$ & 25.46 \\
Yüksek pozitif 2 $\left(10^{-1}\right)$ & 25.44 \\
Yüksek pozitif 3(10-1) & 25.49 \\
Düşük pozitif 1 $\left(10^{-2}\right)$ & 29.41 \\
Düşük pozitif 2 $\left(10^{-2}\right)$ & 29.02 \\
Düşük pozitif 3 $\left(10^{-2}\right)$ & 29.05 \\
\hline
\end{tabular}

olduğu bilinmektedir ${ }^{8,11,12}$. Bu amaçla parazitin genomunda 35 kez tekrarlanan B1 genine ait bir dizinin amplifikasyonu tanımlanmış, parazitin DNA'sının farklı hedef dizilerinin saptanmasına yönelik birçok PCR protokolü geliştirilmiştir. Benzer birçok kalitatif PCR protokollerinin artışı, ciddi bir heterojeniteye neden olmuştur ${ }^{5}$.

Konu ile ilişkili literatür incelendiğinde, B1 genine yönelik primerlerin en sık kullanılan primerlerden biri olduğu görülmüştür. Ayrıca floresan probun duyarlılığı artırması nedeniyle Taqman prob kullanılmasına karar verilmiştir. Bu primerlerle yapılan çalışmalarda saptama sınır değerinin $50 \mu$ reaksiyon hacminde 0.05 takizoit (CT: 39.34) olduğunu bildiren çalışmalar olduğu gibi, $1 \mathrm{ml}$ kanda $9.92 \times 10^{-3}$ ila $8.73 \times 10^{-1}$ takizoit veya 67.7 takizoit olduğunu bildiren çalışmalara da rastlanmıştır $8,13,14$. Çalışmamızda testimizin saptama sınır değeri reaksiyonda 0.028 kopya (CT: 33) olarak belirlenmiştir. Kullandığımız primerler ve prob, T.gondii genomu üzerinde insersiyon sekans gen bölgesini hedef- 


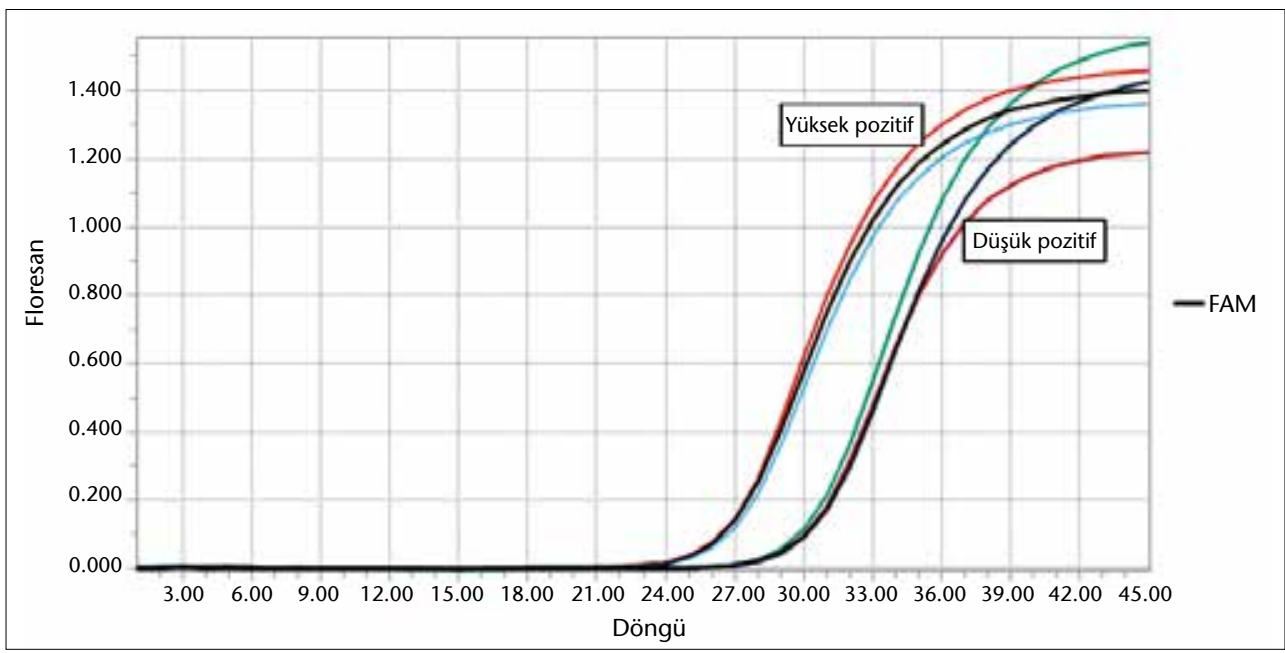

Şekil 3. Kesinlik çalışmasında yüksek pozitif ve pozitif örneklere ait amplifikasyon eğrileri.

Tablo IV. Yöntem Doğrulama Çalışmalarına Ait CV Değerleri

\begin{tabular}{lccc}
\hline & Doğrulama çalışması & $\begin{array}{c}\text { Kesinlik çalışması } \\
\text { (çalışma içi) }\end{array}$ & \\
\hline Yüksek pozitif $(\% C V)$ & 0.62 & 0.62 & 1.03 \\
Düşük pozitif $(\% \mathrm{CV})$ & 0.14 & 0.14 & 2.34 \\
\hline
\end{tabular}

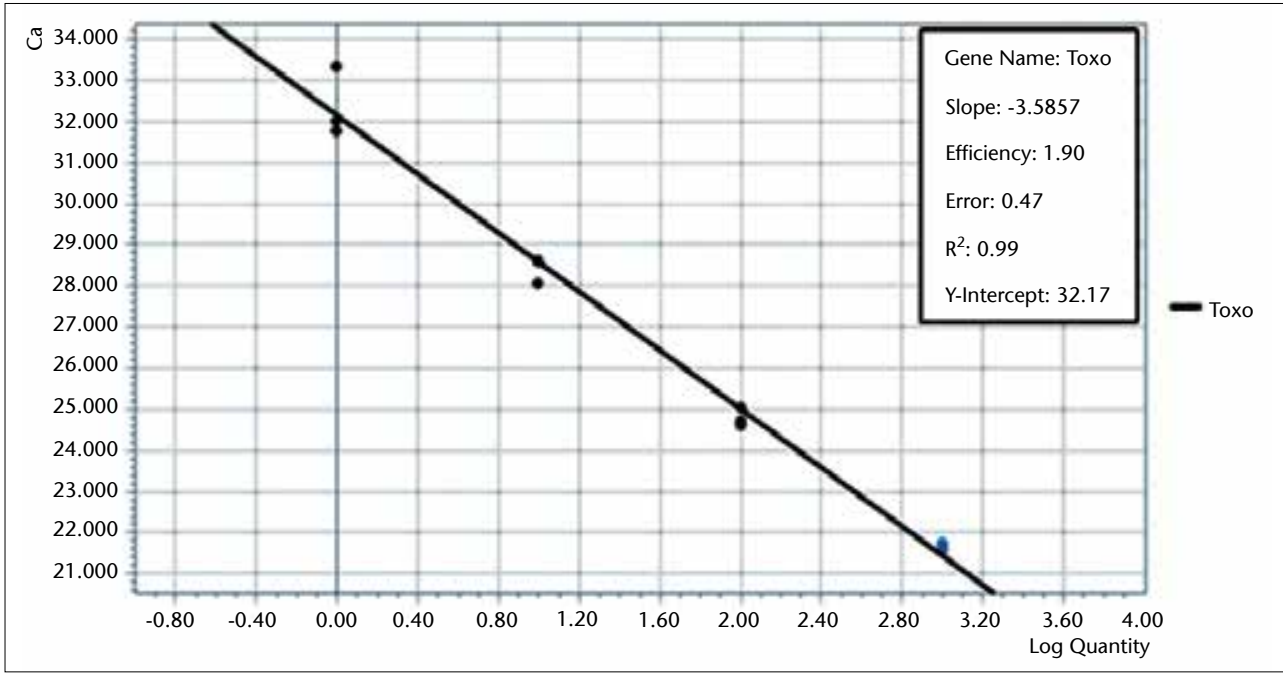

Şekil 4. Testin duyarılığı için T.gondii genomik DNA (28 ila 0.0028 kopya)'sı içeren 10 kat sulandırım serisi amplifiye edilmiştir. Testin verimliliği CT değerlerinin regresyon eğrisi ile ölçülmüş̧ür. CT değerleri ve buna karşılık gelen takizoit sayısına göre elde edilen standart eğri doğrusal bulunmuştur. Ortalama CT değerleri ve T.gondii DNA konsantrasyonları için anlamlı bir korelasyon katsayısı tespit edilmiş $(R=0.99)$, eğim 3.585 olarak belirlenmiştir. 
lediği için ve bir genom üzerinde 300 hedef bölge bulunmasından dolayı saptama sınır değerimizin bu kadar düşük olduğu düşünülmektedir.

Yöntemin validasyon/doğrulama çalışmaları değerlendirildiğinde, CV değerinin oldukça düşük olduğu görülmektedir. Marino ve arkadaşları ${ }^{6}$ T.gondii DNA'sının saptanması için B1 genini hedefleyen nested PCR'yi doğrulama testi olarak kullanarak Taqman prob ile Rt- PCR yönteminin validasyon çalışmasını yapmıştır. Gerçek zamanlı PCR'nin tekrarlanabilirlik çalışmalarının CV değerinin \%0.60 olduğu belirlenmiştir. Lin ve arkadaşları ${ }^{8}$, B1 genine yönelik primerler ve TaqMan prob kullanarak Rt-PCR yöntemi geliştirmiş, çalışma içi CV değeri $\% 0.90, \% 0.16, \% 0.24$ ve \%0.79 olarak belirlenirken, çalışmalar arası CV değeri \%0.4, $\% 0.16, \% 0.24$ ve \%0.79 olarak hesaplanmıştır. Çalışmamızda testin doğruluk çalışması CV değeri yüksek pozitif örnek için 0.62 , düşük pozitif örnek için 0.14 olarak, çalışma içi kesinlik çalışması CV değeri yüksek pozitif örnek için 0.62, düşük pozitif örnek için 0.14 olarak, çalışmalar arası kesinlik çalışması CV değeri yüksek pozitif örnek için 1.03, düşük pozitif örnek için 2.34 olarak hesaplanmış, sonuçlar testin tekrarlanabilir olduğunu göstermiştir.

Doğrulama çalışmaları incelendiğinde, CT değerine karşılık gelen takizoit sayısının belirlendiği standart eğrinin doğrusal olduğu ve $\mathrm{R}=$ 0.99660-0.9988 olarak belirlendiğini bildiren çalışmalara rastlanmıştır ${ }^{2,8}$. Suviriyapaisal ve arkadaşlarının çalışmasında ${ }^{2}$ bu standart eğrinin, optimum sonuçlar için tipik olarak gerekli olan 0.92'lik bir verime sahip olduğu bildirilmiştir. Çalışmamızda elde edilen standart eğri benzer şekilde doğrusal olup $\mathrm{R}=0.99$ olarak belirlenmiş, testimizin verimliğinin uygun olduğuna karar verilmiştir.

Rt-PCR'nin amplifikasyon etkinliğini hesaplamak için standart eğrinin eğimi yaygın olarak kullanılır. Rt-PCR standart eğrisi, nükleik asit miktarına karşılık gelen $\mathrm{CT}$ değerinin yarı logaritmik regresyon çizgisi şeklinde gösterilir. Eğimi -3.32 olan bir standart eğri \%100 verimliliği, -3.32'den daha negatif eğimler (ör. -3.9) \%100'den daha düşük bir verimliliği gösterirken, -3.32'den daha pozitif eğimler (ör. -2.5) örnek kalitesi veya pipetleme problemlerini gösterir. \%100 verimli bir reaksiyon, amplifikasyonun eksponansiyel fazında her 3.32 döngüde PCR amplikonunda 10 kat artış sağlar $\left(\log _{2} 10=3.3219\right)^{15}$. Çalışmamızda elde edilen standart eğrinin eğimi 3.585 olarak belirlenmiştir. Bu durum, DNA kalitesinin iyi olduğunu ve dilüsyonları hazırlarken pipetleme hatası yapılmadığını ortaya koymuştur.

Doğru hedef bölge ve primerler kullanıldığında bile laboratuvar sonucunun kalitesini etkileyen birden fazla faktör sözkonusudur. PCR koşullarının optimizasyonu, DNA ekstraksiyonu-PCR koşulları kombinasyonunun optimizasyonu ve laboratuvarlar arası karşılaştırma veya dış kalite kontrol değerlendirmeleri ile moleküler yöntemlerin standart duyarlılık limitlerinin belirlenmesi önerilmektedir ${ }^{4}$.

Ticari kitlerin uygulanması kolay olmasına rağmen, maliyetlerinin yüksek olması nedeniyle birçok laboratuvar alternatif yöntemler geliştirmeye çalışmaktadır. Ancak bu yöntemler, uygulanan DNA ekstraksiyon yöntemleri, seçilen hedef bölge, amplifikasyon koşulları, kullanılan cihazlar gibi faktörlerin etkisiyle farklı duyarlılık, özgüllük gösterebilmektedir. Çalışmamızın amacı, laboratuvarımızda T.gondii'nin moleküler yöntemle sap- 
tanmasında düşük maliyetli, kantitatif sonuç verebilen, hızlı, güvenilir bir inhouse testi kullanıma sokmaktır. Testin rutin kullanımına başlanmadan önce güvenilir sonuçlar elde edebilmek için standardize edilmesi amacıyla yöntem doğrulama çalışması yapılmış, varyasyon katsayısının \%15'in altında, korelasyon katsayısının 0.99 olduğu belirlenmiş, testin rutin laboratuvar çalışmalarına uygun olduğuna karar verilmiştir.

\section{ÇIKAR ÇATIŞMASI}

Yazarlar bu makale ile ilgili herhangi bir çıkar çatışması bildirmemişlerdir.

\section{KAYNAKLAR}

1. Hashoosh DA, Majeed IA. Comparison of two assays in the diagnosis of toxoplasmosis: immunological and molecular. East Mediterr Health J 2014;20(1):46-50.

2. Suviriyapaisal C, Wanachiwanawin D, Limawongpranee S. Detection of Toxoplasma gondii by PCR and quantitative PCR with high specifity and lower limit of detection. Southeast Asian I Trop Med Public Health 2017;48(4):749-55.

3. Erdoğan $E$, Yürük $M$, Sivcan E, Karaca $S$, Temel H, Şabanoğlu T, et al. Retrospective evaluation of serologic and molecular test results of toxoplasmosis suspected patients. Mikrobiyol Bul 2019;53:96-105.

4. Sterkers Y, Varlet-Marie E, Cassaing S, Brenier-Pinchart MP, Brun S, Dalle F, et al. Multicentric comparative analytical performance study for molecular detection of low amounts of Toxoplasma gondii from simulated specimens. J Clin Microbiol 2010;48(9):3216-22.

5. Oliveira Azevedo CT, Brasil PEAA, Guida L, Lopes Moreira ME. Performance of polymerase chain reaction analysis of the amniotic fluid of pregnant women for diagnosis of congenital toxoplasmosis: a systematic review and meta-analysis. PlosOne 2016;1-26.

6. Marino AMF, Percipalle M, Giunta RP, Salvaggio A, Caracappa G, Alfonzetti T, et al. Development and validation of a real-time PCR assay for the detection of Toxoplasma gondii DNA in animal and meat samples. J Vet Diagn Invest 2017;29(2):203-7.

7. Nagy B, Ban Z, Beke A, Nagy GR, Lazar L, Papp C, et al. Detection of Toxoplasma gondii from amniotic fluid, a comparison of four different molecular biological methods. Clin Chim Acta 2006;368:131-7.

8. Lin MH, Chen TC, Kuo TT, Tseng CC, Tseng CP. Real-time PCR for quantitative detection of Toxoplasma gondii. J Clin Microbiol 2000;38(11):4121-5.

9. Köymen Keser i, Deveci Kocakoç i, Şehirlioğlu AK. A new descriptive statistic for functional data: functional coefficient of variation. Alphanumeric Journal 2016;4(2):1-9.

10. Clark RB, Lewinski MA, Loeffelholz MJ, Tibbetts RJ. Cumitech 31A, verification and validation of procedures in the clinical microbiology laboratory. 2009. Coordinating ed., In: Sharp SE (ed). ASM Press, Washington, DC.

11. Satbige AS, Rajendran C, Patil NA, Sandeep H. Advances in diagnosis of important protozoan diseases: old and new approaches. Int J Curr Microbiol App Sci 2018;7(7):3177-89.

12. Liu Q, Wang ZD, Huang SY, Zhu XQ. Diagnosis of toxoplasmosis and typing of Toxoplasma gondii. Parasites and Vectors 2015;8:292-305.

13. Kompalic-Cristo A, Frotta C, Suárez-Mutis M, Fernandes O, Britto C. Evaluation of a real-time PCR assay based on the repetitive B1 gene for the detection of Toxoplasma gondii in human peripheral blood. Parasitol Res 2007;101(3):619-25.

14. Cardona N, Basto N, Parra B, Zea AF, Pardo CA, Bonelo A, et al. Detection of Toxoplasma DNA in the peripheral blood of HIV-positive patients with neuro-opportunistic infections by a real-time PCR assay. J Neuroparasitol 2011;2:1-6.

15. https://www.gu.se/digitalAssets/1125/1125331_ABI_Guide_Relative_Quantification_using_realtime_PCR. pdf. 